\title{
CHROMIUM (III) COMPLEX OF 2-AMINO-3-CARBOMETHOXY-4,5,6,7-TETRAHYDROBENZO[B] THIOPHENE: SYNTHESIS, CHARACTERIZATION AND ANTIMICROBIAL ACTIVITY
}

\author{
DÉSIRE ANDRÉ SIÉWÉ ${ }^{a}$, EMMANUEL SOPBUÉ FONDJO ${ }^{a *}, J E A N-D E-D I E U T A M O K O U^{b}$, \\ STEVE ENDEGUELE EKOM ${ }^{b}$, KAMAL SOREL DJEUKOUA DIMO ${ }^{a}$, GISCARD DOUNGMO ${ }^{c}$, \\ MALLORY E. WALTERS ${ }^{d}$, APPOLINNAIRE TSOPMO ${ }^{d}$, PETER F. W. SIMON ${ }^{e}$ AND JULES-ROGER KUIATE ${ }^{b}$ \\ ${ }^{a}$ Laboratory of Applied Synthetic Organic Chemistry, Department of Chemistry, Faculty of Science, University of Dschang, P.O. Box 67 Dschang, \\ Republic of Cameroon. \\ ${ }^{b}$ Research Unit of Microbiology and Antimicrobial Substances, Department of Biochemistry, Faculty of Science, University of Dschang, PO Box 067 Dschang, \\ Republic of Cameroon. \\ 'Institut für Anorganische Chemie, Christian-Albrechts-Universität zu Kiel, Max-Eyth-Str. 2, 24118 Kiel, Germany \\ ${ }^{d}$ Department of Chemistry, Carleton University, 1125 Colonel By Drive K1S 5B6, Ottawa, Canada +1-613-520-260 Ext 3122. \\ ePolymer Chemistry Laboratory, Faculty of Live Sciences, Rhine-Waal University of Applied Sciences, Campus Kleve, Marie-Curie Strasse 1, D-47533 Kleve, \\ Germany.
}

\begin{abstract}
A new chromium (III) coordination compound of 2-amino-3-carbomethoxy-4,5,6,7-tetrahydrobenzo[b]thiophene (ACTT) $(3)$ with $\mathrm{Cr}\left(\mathrm{NO}_{3}\right)_{3} .9 \mathrm{H}_{2} \mathrm{O}$ in methanol at room temperature for 48 hours has been prepared. The composition of the new complex compound (4) has been confirmed by a number of instrumental methods including IR, NMR, MS and elemental analysis. It was found that the ACTT ligand behaves as bidentate chelating agent and coordinates to the central metal ion through the nitrogen atom of the amino-group and the oxygen atom of the carbonyl function of the ester group. The results showed that in the coordination sphere of the complex, the metal ion is coordinated by three chelating ACTT ligands. In the structure of the cation core $\left[\mathrm{Cr}(\mathrm{ACTT})_{3}\right]^{3+}$, the three ACTT ligands are linked to the chromium ion through three $\mathrm{Cr}-\mathrm{N}$ and three $\mathrm{Cr}-\mathrm{O}$ bonds forming a square bipyramidal geometry. The metal complex and the ACTT ligand were screened for their antimicrobial activities against several strains of bacteria (Staphylococcus aureus ATCC25923, Escherichia coli S2 (1), Bacillus subtilis, Staphylococcus aureus, Pseudomonas aeruginosa ATCC27853, Shigella flexneri SDINT) and fungi (Candida albicans ATCC10231, Candida tropicalis PK233, Cryptococcus neoformans H99). The chromium complex showed promising antimicrobial activity against the microorganisms with minimum inhibitory values between 4 and $16 \mu \mathrm{g} / \mathrm{mL}$.
\end{abstract}

Keywords: Antimicrobial, Complexation reaction, 4,5,6,7-tetrahydrobenzo[b]- thiophene, Chromium complex.

\section{INTRODUCTION}

Synthetic organic compounds containing 4,5,6,7-tetrahydrobenzo[b]thiophene scaffold in their structures have been the subject of intensive investigations in the recent years. This class of compounds are known to exhibit good properties like antimicrobial [1,2], anti-Alzheimer [3], antitumor and cytotoxic [4,5], antifungal [6,7], anti-leishmanial [8,9], antioxidant [10], kinase inhibitor, anti-leishmanial [5], murf inhibitor [11]. They also find applications in optic, electronic [12-15] and dyestuff $[13,16,17]$ industries.

First row transition metal compounds are well known to exhibit properties like pharmacological [18,19], conductor [20,21], and light emitting devices (LEDs) [22], nonlinear optical devices (NLO) [23], photo switch [24,25], and nanomaterial [26]. In addition, natural first row transition metals compounds are also found in biological system such as hemoglobin [27], vitamin B12 [27], metalloenzymes [27], and catalytic protein [27]. All these natural complexes facilitate a multitude of vital chemical reactions needed for life.

The issue of antimicrobial resistance of bacteria such as Staphylococcus aureus [28,29], Escherichia coli S2 (1) [30,31], Bacillus subtilis [32], Pseudomonas aeruginosa ATCC27853 [33,34], Shigella flexneri SDINT [35,36], and fungi such as Candida albicans ATCC10231 [37,38], Candida tropicalis PK233 [39,40], Cryptococcus neoformans H99 [41,42] to conventional antibiotic and antifungal prophylaxis is currently the cause of an increasingly serious threat to the global public health. Among the solutions that can be envisaged for the mitigation of this threat, greater innovation and development of new antimicrobials are important. The formation of heterocyclic scaffolds and the resulting clusters incorporating biologically relevant metals are among the broad promising pathway that can lead to the discovery of new synthetic antimicrobial agents. We therefore became interested in the coordination chemistry of 2 amino-3-carbomethoxy-4,5,6,7-tetrahydrobenzo[b]thiophene ligands with transition metals and the biological applications of the resulting compounds motivated by good result obtain by the same ligand at room temperature with $\mathrm{BiCl}_{3}$ salt [43]. In the present work we investigated the reaction at room temperature of 2-amino-3-carbomethoxy-4,5,6,7-tetrahydrobenzo[b]thiophene
(ACTT) with the first row transition metal salts including $\mathrm{CuSO}_{4}$, $\mathrm{Cr}\left(\mathrm{NO}_{3}\right)_{3} \cdot 9 \mathrm{H}_{2} \mathrm{O}, \mathrm{Co}\left(\mathrm{C}_{2} \mathrm{O}_{4}\right) \cdot \mathrm{H}_{2} \mathrm{O}, \mathrm{MnCl}_{2} \cdot 4 \mathrm{H}_{2} \mathrm{O}, \mathrm{NiCl}_{2} \cdot 6 \mathrm{H}_{2} \mathrm{O}, \mathrm{Co}\left(\mathrm{NO}_{3}\right)_{2} \cdot 6 \mathrm{H}_{2} \mathrm{O}$ $\mathrm{FeCl}_{3} \cdot 6 \mathrm{H}_{2} \mathrm{O}$. From all these reactions only the one with $\mathrm{Cr}$ (III) salt effectively gave a new complex compound which was characterized by its spectrometric and spectroscopic data. The new compound was further screened for its antibacterial and antifungal activities against strains of bacteria and fungi.

\section{EXPERIMENTAL}

\section{Chemistry Section}

All melting points are corrected and were determined with a STUART SCIENTIFIC Melting Point Apparatus Model SMP3 at a speed of $1.5^{\circ} \mathrm{C} / \mathrm{min}$. The TLCs were carried out on Eastman Chromatogram Silica Gel Sheets (13181; 6060) with fluorescent indicator. A mixture of ethyl acetate and methylene chloride (1:1) was used as eluent and iodine was used as standard for the chromatograms. The IR spectrum was measured with pure sample on a Fourier Transform Infrared spectrometer (Bruker Alpha). EIMS spectra were recorded on a double focusing mass spectrometer (Varian MAT 311A). ${ }^{1} \mathrm{H}-\mathrm{NMR}$ spectra were recorded in DMSO- $\mathrm{d}_{6}$ on a Bruker DRX spectrometer operating at 400 MHz. ${ }^{13} \mathrm{C}-\mathrm{NMR}$ spectra were recorded in DMSO- $\mathrm{d}_{6}$ on a Bruker DRX spectrometer operating at $100 \mathrm{MHz}$. TMS was used as internal reference. All the reagents mentioned in this work were purchased from Aldrich and Fluka and were used without further purification. Elemental analyses were performed With a Euro Vector CHNS-O element analyzer (Euro EA 3000) or a vario MICRO Cube (Co. Elementar Analysensysteme).

Preparation of 2-amino-3-carbomethoxy-4,5,6,7-tetrahydrobenzo[b] thiophene (ACTT)

A mixture of cyclohexanone $\left(\mathrm{C}_{6} \mathrm{H}_{10} \mathrm{O}, 50 \mathrm{mmol}, 4.9 \mathrm{~g}\right)$, methyl cyanoacetate $\left(\mathrm{C}_{4} \mathrm{H}_{5} \mathrm{NO}_{2}, 50 \mathrm{mmol}, 4.95 \mathrm{~g}\right)$ and sulphur $\left(\mathrm{S}_{8}, 55 \mathrm{mmol}, 1.76 \mathrm{~g}\right)$ in methanol $\left(\mathrm{CH}_{3} \mathrm{OH}, 80 \mathrm{~mL}\right)$ was stirred using a magnetic plate shaker at $50-60{ }^{\circ} \mathrm{C}$. Ammonia $\left(\mathrm{NH}_{3}, 5 \mathrm{~mL}\right)$ was added dropwise during the first $10 \mathrm{~min}$ of the reaction. After $3 \mathrm{~h}$ of reaction, the resulting precipitate was collected by filtration 
and crystallized from methanol $\left(\mathrm{CH}_{3} \mathrm{OH}\right)$ to yield a yellow powder $(8.66 \mathrm{~g}, 82 \%)$, mp 133-135 ${ }^{\circ} \mathrm{C}$ (Lit. [44] 127-128 ${ }^{\circ} \mathrm{C}$ from methanol); Anal. calcd. for $\mathrm{C}_{10} \mathrm{H}_{11} \mathrm{NSO}_{2}: \mathrm{C}, 56.872 ; \mathrm{H}, 6.161 ; \mathrm{N}, 6.635 ; \mathrm{S}, 15.165$; Found: $\mathrm{C}, 56.870 ; \mathrm{H}$, $6.158 ; \mathrm{N}, 6.633 ; \mathrm{S}, 15.168$; FT-IR data (neat, $\left.\mathrm{v} / \mathrm{cm}^{-1}\right): 3419,3310\left(-\mathrm{NH}_{2}\right), 3153$ $\left(-\mathrm{OCH}_{3}\right), 1649(\mathrm{C}=\mathrm{O}), 1585,1575(\mathrm{C}=\mathrm{C}), 775 ; 734(\mathrm{C}-\mathrm{S}), 1332(\mathrm{C}-\mathrm{N}), 1268(\mathrm{C}-$ O); ${ }^{1} \mathrm{H}-\mathrm{NMR}\left(\mathrm{DMSO}_{-} \mathrm{d}_{6}\right) \delta_{\mathrm{H}}: 7.17$ (s, $\left.2 \mathrm{H},-\mathrm{NH}_{2}\right), 3.61\left(\mathrm{~s}, 3 \mathrm{H},-\mathrm{OCH}_{3}\right), 2.52(\mathrm{~s}$, $2 \mathrm{H}, \mathrm{CH}_{2}$ ring), 2.46 (s, $2 \mathrm{H}, \mathrm{CH}_{2}$ ring), 2.36 (s, $2 \mathrm{H}, \mathrm{CH}_{2}$ ring), 1.61 (s, $2 \mathrm{H}, \mathrm{CH}_{2}$ ring); ${ }^{13} \mathrm{C}-\mathrm{NMR}$ (DMSO-d ${ }_{6}$ ) $\delta_{\mathrm{C}}: 165.87,163.41,131.83,115.93,102.90,50.77$, 26.97, 24.41, 23.34, 22.87.

\section{Preparation of metal complex}

To a magnetically stirred solution of the ligand $(0.32 \mathrm{~g} ; 1.5 \mathrm{mmol})$ in methanol $\left(\mathrm{CH}_{3} \mathrm{OH}, 10 \mathrm{~mL}\right)$, a solution of metal salt $\mathrm{Cr}\left(\mathrm{NO}_{3}\right)_{3} .9 \mathrm{H}_{2} \mathrm{O}(0.4 \mathrm{~g}, 1 \mathrm{mmol})$ in methanol $\left(\mathrm{CH}_{3} \mathrm{OH}, 10 \mathrm{~mL}\right)$ was added dropwise. The mixture was stirred at room temperature for $48 \mathrm{~h}$. Afterwards the orange precipitate formed was collected by filtration and crystallized from the mixture water/methanol to give $0.19 \mathrm{~g}(53 \%)$ of compound 4 as orange powder, mp $170{ }^{\circ} \mathrm{C}$; Anal. calcd. for $\mathrm{C}_{30} \mathrm{H}_{45} \mathrm{~N}_{6} \mathrm{~S}_{3} \mathrm{O}_{18} \mathrm{Cr}$ : C, 38.852, H, 4.908, N, 9.102, S, 10.380; Found: C, 38.590, H, 5.325, N, 9.206, S, 10.275; FT-IR data (neat, $\left.\mathrm{v} / \mathrm{cm}^{-1}\right): 3454,3332\left(-\mathrm{NH}_{2}\right), 1671,1647(\mathrm{C}=\mathrm{O}), 1576$ $(\mathrm{C}=\mathrm{C}), 778,733(\mathrm{C}-\mathrm{S}), 1334(\mathrm{C}-\mathrm{N}), 1268(\mathrm{C}-\mathrm{O}), 574(\mathrm{Cr}-\mathrm{O}), 411(\mathrm{Cr}-\mathrm{N}) ;{ }^{1} \mathrm{H}-$ NMR (DMSO-d $\left.{ }_{6}\right) \delta_{\mathrm{H}}: 7.74,7.69,7.30,4.64,4.62,3.78,3.62,3.58,3.44,3.33$, $1.94,1.91,1.66,1.64,1.62,1.61,1.59 ;{ }^{13} \mathrm{C}-\mathrm{NMR}\left(\mathrm{DMSO}-\mathrm{d}_{6}\right) \delta_{\mathrm{C}}: 166.65,165.88$, $165.17,132.03,131.84,130.32,121.00,116.26,115.95,102.08,101.31,56.55$, $51.75,51.06,50.94,50.77,27.78,26.98,24.57,24.42,24.11,23.36,23.34$, $22.89,19.08,18.43$

\section{Biology Section}

\section{Microorganisms}

Six bacteria and three yeasts were tested for their susceptibility to the studied compounds. The studied microorganisms are Staphylococcus aureus (ATCC25923), Escherichia coli S2 (1), Bacillus subtilis, Staphylococcus aureus, Pseudomonas aeruginosa (ATCC27853), Shigella flexneri SDINT, Candida albicans (ATCC10231), Candida tropicalis (PK233) and Cryptococcus neoformans (H99) taken from our laboratory collection. The bacterial and fungal species were maintained on agar slant at $+4{ }^{\circ} \mathrm{C}$ and subcultured at $37{ }^{\circ} \mathrm{C}$ on nutrient agar (NA, Conda, Madrid, Spain) and Sabouraud Dextrose Agar (SDA, Conda) slants respectively, prior to any antimicrobial test.

Determination of Minimum Inhibitory Concentration (MIC) and Minimum Microbicidal Concentration (MMC)

MIC and MMC values were determined as described earlier [45]. Each test sample was dissolved in 10\% (v/v) aqueous Dimethylsulfoxide (DMSO) solution (Fisher chemicals, Strasbourg, France). The MICs were assessed visually and were taken as the lowest compound concentration at which there was no growth or virtually no growth. The lowest concentration that yielded no growth after the sub-culturing was considered as the minimum microbicidal concentrations (MMCs). Ciprofloxacin (Sigma-Aldrich, Steinheim, Germany) and nystatin (Merck, Darmstadt, Germany) were used as positive controls for bacteria and yeasts, respectively. Broth with $1 \%$ DMSO was used as a negative control. All the tests were performed in triplicate and repeated three times with similar results.

\section{RESULTS AND DISCUSSION}

\section{Chemistry Section}

The ligand 2-amino-3-carbomethoxy-4,5,6,7-tetrahydrobenzo[b]thiophene (3) was synthesized as shown in scheme 2 by applying the second version of the Gewald [44] methodology. All the physical, spectroscopic and analytical data of compound 3 were in full agreement with those previously reported [44]. Upon treatment of $\mathbf{3}$ with chromium (III) nitrate nonahydrate and subsequent work up, a compound was isolated to which structure 4 was assigned based on its elemental analysis and spectroscopic data as follows.

\section{IR spectrum study of ligand and complex}

The comparison of the IR spectrum of the ligand (3) with that of the complex (4) showed the presence of strong bands assigned to the elongation frequency
$v\left(\mathrm{NH}_{2}\right)$ of the aromatic amine, were found respectively at $3419 \mathrm{~cm}^{-1}$ (very strong) and $3310 \mathrm{~cm}^{-1}$ (very strong) for ligand and at $3454 \mathrm{~cm}^{-1}$ (average strong), 3332 $\mathrm{cm}^{-1}$ (average strong) for complex. The presence of these two bands of the amino group in the IR spectrum of the complex, may suggest that complexation occurred without deprotonation of the primary amine.

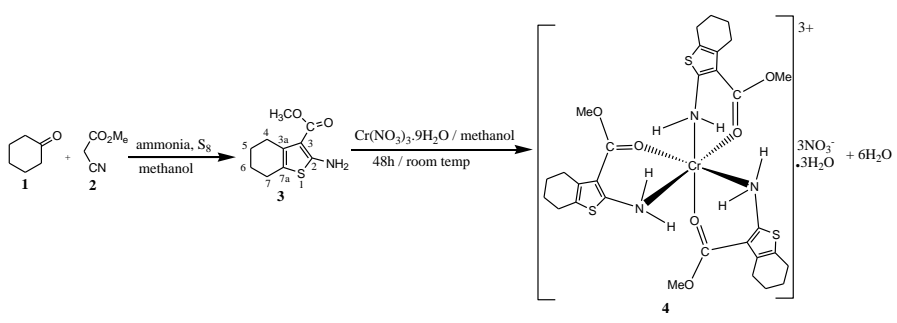

Scheme 1. Reactions sequences to $\mathrm{Cr}(\mathrm{ACTT})_{3}\left(\mathrm{NO}_{3}\right)_{3}\left(\mathrm{H}_{2} \mathrm{O}\right)_{3}$ complex 4.

In addition, a positive shift of these bands to higher frequencies $\left(\Delta v=+35 \mathrm{~cm}^{-1}\right.$ and $\Delta v=+22 \mathrm{~cm}^{-1}$ respectively) in complex (4), may be due to the participation of the nitrogen atom of the amino group to coordination [46]. The IR spectrum also exhibited strong bands at $1649 \mathrm{~cm}^{-1}$ for compound (3) and $1647 \mathrm{~cm}^{-1}$ for the complex. These absorptions are characteristic of the carbonyl function of the ester group. The shift of this band to weak wave number in the complex may be due to the participation of the carbonyl function's oxygen atom to the coordination. The low downshift of this band during coordination may be due to the nature of the central metal ion. These observations is in agreement with the well-known Irving-Williams' magnitudes order of the shifts: $\mathrm{Mn}$ (II) $<\mathrm{Fe}$ (II) < $\mathrm{Co}$ (II) $<\mathrm{Ni}$ (II) $<\mathrm{Cu}$ (II) $>\mathrm{Zn}$ (II) [47]. Furthermore, it was noticed that, the absorption bands $v(C-S)$ in the ligand $\left(775 \mathrm{~cm}^{-1}\right.$ and $\left.734 \mathrm{~cm}^{-1}\right)$ were poorly affected in complex $\left(778 \mathrm{~cm}^{-1}\right.$ and $\left.733 \mathrm{~cm}^{-1}\right)$. On the other hand, the four member rings that may result from the coordination of the chromium ion with the sulfur atom of the thiophenic ring and the nitrogen atom may be thermodynamically unfavorable [48].

The absence of characteristic $v\left(\mathrm{H}_{2} \mathrm{O}\right)$ absorption bands in the range 3600-3200 $\mathrm{cm}^{-1}$ and characteristics $\gamma\left(\mathrm{H}_{2} \mathrm{O}\right)$ out of plane deformation frequency bands around $700-800 \mathrm{~cm}^{-1}$ in the IR spectrum of the complex clearly indicates that water molecules are not involved in the coordination reaction [47]. However, the presence of the characteristics $\delta\left(\mathrm{H}_{2} \mathrm{O}\right)$ in plane deformation frequency band around $1600 \mathrm{~cm}^{-1}$ in the IR spectrum of the complex confirms the presence of non-coordinated $\mathrm{H}_{2} \mathrm{O}$ molecules in the complex [47]. The new bands found around $1509 \mathrm{~cm}^{-1}$ and $1311 \mathrm{~cm}^{-1}$, respectively, may be due to the stretching vibration of the nitrate ions. The $v(\mathrm{M}-\mathrm{O})$ and $v(\mathrm{M}-\mathrm{N})$ vibration bands were found around $574 \mathrm{~cm}^{-1}$ and $411 \mathrm{~cm}^{-1}$ respectively and assigned to the metal-heteroatom linkages $(\mathrm{Cr}-\mathrm{O}$ and $\mathrm{Cr}-\mathrm{N})[49,50]$.

\section{${ }^{13} \mathrm{C}$-NMR study of ligand and complex}

The ${ }^{13} \mathrm{C}$-NMR spectrum exhibits three signals at $\delta_{\mathrm{C}}=166.65,165.88$ and $165.17 \mathrm{ppm}$ assigned to the carbonyl functions of the ester groups in agreement with the presence of three coordinated ACTT ligand in the complex. Table 1 compares the ${ }^{1} \mathrm{H}$ and ${ }^{13} \mathrm{C}$-NMR data of the ligand $\mathbf{3}$ with those of the complex 4 In this Table, each signal of individual carbon atoms in the starting free 2 aminothiophene ligand $\mathbf{3}$ is splitted in a number of corresponding signals attributed to the three coordinated ligands to the chromium (III) ion in the complex compound 4 . An accurate assignment of these signals to each individual coordinated ACTT ligand in the complex is however not possible due to the complexity of the complex's molecule and unavoidable overlapping.

\section{${ }^{1}$ H-NMR study of ligand and complex}

Upon comparing the ${ }^{1} \mathrm{H}-\mathrm{NMR}$ data of the complex $\mathbf{4}$ with those of the starting 2-aminothiophene $\mathbf{3}$, one can realize that to each individual signal or groups of chemically and magnetically equivalent hydrogen atoms in the starting free ligand 3 correspond a number of analogous signals assigned to the three coordinated 2-aminothiophene ligands to the central chromium (III) ion in the complex 4 (Table 1). For similar reasons mentioned above, no accurate assignment of these signals to each coordinated ACTT ligand was made. 


\section{D-NMR-spectrum of complex 4 and ligand 3}

The analyses of various 2D-NMR data (Table 2) brought further evidences in favor of the suggested structure of complex 4 .

The HSQC spectrum of ligand shows five spots of correlation corresponding to the five protonated carbons of the compound. A correlation spot is also found between the methoxyl protons at $\delta_{\mathrm{H}}=3.61 \mathrm{ppm}$ and the corresponding carbon at $\delta_{\mathrm{C}}=50.8 \mathrm{ppm}$. The signal appearing at $\delta_{\mathrm{H}}=7.18 \mathrm{ppm}$ shows no correlation with any carbon. This signal was therefore readily assigned to the $-\mathrm{NH}_{2}$ protons. The carbon atoms of the cyclohexane ring bearing hydrogen atoms were detected due to the correlation spots observed between the signals at $\delta_{\mathrm{C}}=22.9,27.0,24.4$, $23.3 \mathrm{ppm}$ and $\delta_{\mathrm{H}}=1.62,2.52,2.35,1.62 \mathrm{ppm}$ respectively. The analogous assignments have been made for the complex by just comparing the HSQC spectrum of ligand with that of the complex. The unambiguous assignments of the various carbon atoms in the ligand's molecule could be made because of the rationalization of the correlations' spots shown by the HMBC technique. The $J^{3}$ interactions between the methoxyl protons and the carbon atom of the carbonyl function are materialized by the correlation's spot observed at $\left(\delta_{\mathrm{C}}, \delta_{\mathrm{H}}\right)=(165.9$, 3.62). The other important HMBC interactions are recapitulated in Table 2. Upon comparing the HMBC data of the complex with those of the ligand, it appears that for each set of correlations of the ligand, a number of homologous sets of correlations could be found for the complex. However, it is practically impossible to rationally assign each individual set of correlations to each individual three coordinated ligands because of the complexity of the overlapping of the signals of homologous proton systems of the ligand units. The spatial proximity of the $-\mathrm{NH}_{2}$ and $-\mathrm{OCH}_{3}$ groups is highlighted by the NOESY experiment for the ligand and for the complex as well. In both cases, correlation spots are observed at $\left(\delta_{\mathrm{H}}, \delta_{\mathrm{H}}\right)=(7.18,3.62)$ for the ligand and at $\left(\delta_{\mathrm{H}}, \delta_{\mathrm{H}}\right)=(7.74$, $3.44),(7.72,3.44),(7.33,3.32)$ for the complex respectively.

Table 1. Comparison of the ${ }^{1} \mathrm{H} \&{ }^{13} \mathrm{C}-\mathrm{NMR}$ (DMSO- $\mathrm{d}_{6}$ ) chemical shifts of the ligand 3 with those of the complex 4 .

\begin{tabular}{|c|c|c|c|c|}
\hline \multirow{2}{*}{$\mathrm{N}^{\circ} \mathrm{C} / \mathrm{H}$} & \multicolumn{2}{|c|}{ Ligand $\mathbf{3}$} & \multicolumn{2}{|c|}{ Complex 4} \\
\hline & ${ }_{\mathrm{H}}^{1}$ in $\mathrm{ppm}$ & ${ }_{\mathrm{C}}^{13}$ in $\mathrm{ppm}$ & ${ }_{\mathrm{H}}^{1}$ in $\mathrm{ppm}$ & ${ }_{\mathrm{C}}^{13}$ in ppm \\
\hline 2 & ----------- & 102.91 & ----------- & $102.08,101.31$ \\
\hline 3 & ------------- & 131.83 & ------------ & $132.03,131.84,130.32$ \\
\hline $3 a$ & ----------- & 115.93 & ------------ & $121.00,116.26,115.95$ \\
\hline 4 & 1.62 & 22.87 & 1.66 & $22.89,22.87$ \\
\hline 5 & 2.52 & 26.97 & $2.55,2.51,2.50$ & $27.78,26.98$ \\
\hline 6 & 2.35 & 24.41 & 2.45 & $24.57,24.42$ \\
\hline 7 & 1.62 & 23.34 & 1.66 & $24.11,23.36,23,34$ \\
\hline $7 \mathrm{a}$ & 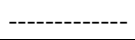 & 163.41 & ------------- & $163.92,163.74,163.40$ \\
\hline $\mathrm{C}=\mathrm{O}$ & |----------- & 165.88 & |----------- & $166.65,165.88,165.17$ \\
\hline$-\mathrm{OCH}_{3}$ & 3.62 & 50.76 & $3.62,3.58,3.32 .3 .43,4.56$ & $51.75,51.06,50.94,50.77$ \\
\hline$-\mathrm{NH}_{2}$ & 7.18 & |---------- & $7.74,7.72,7.33$ & ----------- \\
\hline
\end{tabular}

The $\mathrm{H}, \mathrm{H}-\mathrm{COSY}$ interactions in the ligand are exhibited at $\left(\delta_{\mathrm{H}}, \delta_{\mathrm{H}}\right)=(1.62$, $2.52),(1.62,2.35),(2.52,1.62),(2.35,1.62)$; whereas for the complex, the correlations are displayed at $\left(\delta_{\mathrm{H}}, \delta_{\mathrm{H}}\right)=(1.61,1.91),(1.61,2.55),(1.61,4.62)$, $(1.62,1.91),(1.62,4.62),(1.62,2.55),(2.51,4.62),(2.51,1.91),(1.91,4.62)$, (1.91, 1.91), (1.59, 4.62), (1.59, 1.91), (2.56, 1.66), (2.56, 7.72), (2.38, 1.66), $(2.38,7.72),(2.45,1.66),(2.45,7.72),(2.55,1.62),(2.55,1.66),(2.55,2.45)$, (2.45, 1.62), (2.45, 1.66), (2.45, 2.45), (1.66, 1.62), (1.66, 1.66), (1.66, 2.45), $(4.62,1.91),(4.62,1.61),(3.44,1.91),(3.44,1.61),(3.58,1.91)$ and $(3.58,1.61)$ are in agreement with the complexity of the overlapping of homologous signals of the coordinated ACTT ligands. This makes it practically impossible to assign in a rational way any given set of correlations to any singular coordinated ligand.

\section{Mass spectrum of complex 4}

The mass spectrum of compound $\mathbf{4}$ exhibited characteristic ion fragments such as $\left[\mathrm{Cr}\left(\mathrm{C}_{10} \mathrm{H}_{13} \mathrm{NSO}_{2}\right)_{3}\left(\mathrm{NO}_{3}\right)_{2}+\left(\mathrm{CH}_{3} \mathrm{OH}\right)_{6}\right]^{+}(\mathrm{m} / \mathrm{z}=1000)$, $\left[\mathrm{Cr}\left(\mathrm{C}_{10} \mathrm{H}_{13} \mathrm{NSO}_{2}\right)_{3}\left(\mathrm{NO}_{3}\right)_{2} \cdot\left(\mathrm{H}_{2} \mathrm{O}\right)_{2}+\left(\mathrm{CH}_{3} \mathrm{OH}\right)_{3}\right]^{+}(\mathrm{m} / \mathrm{z}=941)$, $\left[\mathrm{Cr}\left(\mathrm{C}_{10} \mathrm{H}_{13} \mathrm{NSO}_{2}\right)_{3}\left(\mathrm{NO}_{3}\right)_{2} \cdot\left(\mathrm{H}_{2} \mathrm{O}\right)_{2}+\mathrm{CH}_{3} \mathrm{OH}\right]^{+}(\mathrm{m} / \mathrm{z}=877)$, $\left[\mathrm{Cr}\left(\mathrm{C}_{10} \mathrm{H}_{13} \mathrm{NSO}_{2}\right)_{3} \mathrm{NO}_{3} \cdot \mathrm{H}_{2} \mathrm{O}+\left(\mathrm{CH}_{3} \mathrm{OH}\right)_{3}\right]^{2+}(\mathrm{m} / \mathrm{z}=861),\left[\mathrm{Cr}\left(\mathrm{C}_{10} \mathrm{H}_{13} \mathrm{NSO}_{2}\right)_{3}+\right.$ $\left.\left(\mathrm{CH}_{3} \mathrm{OH}\right)_{3}\right]^{3+}(\mathrm{m} / \mathrm{z}=780), \quad\left[\mathrm{Cr}\left(\mathrm{C}_{10} \mathrm{H}_{13} \mathrm{NSO}_{2}\right)_{2}\left(\mathrm{NO}_{3}\right)_{2} \cdot\left(\mathrm{H}_{2} \mathrm{O}\right)_{3}\right]^{+}(\mathrm{m} / \mathrm{z}=652)$, $\left[\mathrm{Cr}\left(\mathrm{C}_{10} \mathrm{H}_{13} \mathrm{NSO}_{2}\right)_{2} \mathrm{NO}_{3}\right]^{2+}(\mathrm{m} / \mathrm{z}=536),\left[\mathrm{Cr}\left(\mathrm{NO}_{3}\right)_{2} \cdot\left(\mathrm{H}_{2} \mathrm{O}\right)_{2}\right]^{+}(\mathrm{m} / \mathrm{z}=212)$, $\left[\mathrm{Cr}\left(\mathrm{NO}_{3}\right)_{2} \cdot \mathrm{H}_{2} \mathrm{O}\right]^{+}(\mathrm{m} / \mathrm{z}=194),\left(\mathrm{C}_{10} \mathrm{H}_{12} \mathrm{NSO}_{2}\right)^{+}(\mathrm{m} / \mathrm{z}=210),\left[\mathrm{CrNO}_{3}\right]^{2+}(\mathrm{m} / \mathrm{z}=$ 114), $\left[\mathrm{Cr}\left(\mathrm{H}_{2} \mathrm{O}\right)_{3}\right]^{3+}(\mathrm{m} / \mathrm{z}=106)$ in agreement with the suggested structure.

Table 2. Comparison of the interactions in the ${ }^{1} \mathrm{H} \&{ }^{13} \mathrm{C}-2 \mathrm{D}-\mathrm{NMR}\left(\mathrm{DMSO}-\mathrm{d}_{6}\right.$ ) chemical shifts of the ligand $\mathbf{3}$ with those of the complex 4.

\begin{tabular}{|c|c|c|c|c|c|c|c|c|c|c|}
\hline \multicolumn{6}{|c|}{ Ligand $\mathbf{3}$} & \multicolumn{5}{|c|}{ Complex 4} \\
\hline $\mathrm{N}^{\circ} \mathrm{C}$ & $\delta_{\mathrm{C}}$ & HSQC & HMBC & COSY & NOESY & $\delta_{\mathrm{C}}$ & HSQC & HMBC & COSY & NOESY \\
\hline 2 & 102.9 & $|--------|$ & $3.62 ; 2.52$ & ---------- & ---------- & $102.1 ; 101.3 ; 101.3$ & ---------- & 7.74; 7.72; & ---------- & ---------- \\
\hline 3 & 131.6 & $|--------|$ & $2.52 ; 2,35 ; 1.62$ & ---------- & ---------- & $132.0 ; 131.8 ; 130.3$ & --------- & $7.74 ; 7.72 ; 4.62$ & ---------- & ---------- \\
\hline $3 a$ & 115.9 & $|--------|$ & $2.52 ; 2.35 ; 1.62$ & ---------- & ---------- & $121.0 ; 116.3 ; 116.0$ & --------- & $\begin{array}{c}4.62 ; 2.55 ; 2.38 ; \\
1.66\end{array}$ & ---------- & --------- \\
\hline 4 & 22.9 & 1.62 & 1.62 & $2.52 ; 2.35$ & ---------- & $22.89 ; 19.06 ; 18.43$ & $1.61 ; 1.62$ & $2.51 ; 2.38$ & $1.91 ; 2.55 ; 4.62$ & ---------- \\
\hline 5 & 27.0 & 2.52 & $2.36 ; 1.62$ & 1.62 & ---------- & $27.7 ; 27.0 ; 27.0$ & $2.51 ; 1.91 ; 1.59$ & $2.51 ; 1.66$ & $4.62 ; 1.91$ & --------- \\
\hline 6 & 24.4 & 2.35 & 1.62 & 1.62 & ---------- & $24.6 ; 24.4 ; 24.1$ & $2.56 ; 2.38 ; 2.45$ & $1.66 ; 1.66 ; 1.66$ & $1.66 ; 7.72$ & ---------- \\
\hline 7 & 23.3 & 1.62 & $2.52 ; 2.35 ; 1.62$ & $2.52 ; 2.35$ & ---------- & $23.4 ; 23.4 ; 23.3$ & $2.55 ; 2.45 ; 1.66$ & $2.55 ; 2.45 ; 1.61$ & $1.62 ; 1.66 ; 2.45$ & --------- \\
\hline $7 \mathrm{a}$ & 163.9 & \begin{tabular}{|l|}
------- \\
\end{tabular} & $\begin{array}{l}--{ }^{\prime}----- \\
\end{array}$ & --------- & --------- & $163.9 ; 163.7 ; 163.4$ & --------- & $7.74 ; 7.72 ; 4.62$ & --------- & --------- \\
\hline $\mathrm{C}=\mathrm{O}$ & 165,9 & & 3.62 & ---------- & ---------- & $166.7 ; 165.8 ; 165.2$ & ---------- & $3.76 ; 3.61$ & ---------- & ---------- \\
\hline $\mathrm{OCH}_{3}$ & 50,8 & 3.62 & --------- & --------- & 7.18 & $51.8 ; 51.2 ; 50.9$ & $\begin{array}{c}4.62 ; 3.32 ; 3.44 ; \\
3.58\end{array}$ & --------- & $1.91 ; 1.61 ;$ & $7.74 ; 7.33$ \\
\hline $\mathrm{NH}_{2}$ & - & $|-------|$ & 7.18 & --------- & 3.62 & --------- & --------- & $7.74 ; 7.72 ; 7.33$ & $4.62 ; 2.56$ & $3.44 ; 3.32$ \\
\hline
\end{tabular}




\section{Elemental analysis of complex 4}

Table 3. Elemental analysis data of complex 4.

\begin{tabular}{|c|c|c|}
\hline Chemical element & Calculated Values (\%) & Found Values (\%) \\
\hline Carbon $(\mathrm{C})$ & 38.852 & 38.590 \\
\hline Hydrogen $(\mathrm{H})$ & 4.908 & 5.325 \\
\hline Nitrogen $(\mathrm{N})$ & 9.102 & 9.206 \\
\hline Sulfur $(\mathrm{S})$ & 10.380 & 10.275 \\
\hline
\end{tabular}

From the elemental analysis data (Table 3 ) for compound $\mathbf{4}$, one can deduce the gross formulae $\mathrm{C}_{30} \mathrm{H}_{45} \mathrm{~N}_{6} \mathrm{~S}_{3} \mathrm{O}_{18} \mathrm{Cr}$ which corresponds to the molecular weight $925.17 \mathrm{~g} / \mathrm{mol}$ and the stoichiometric formulae $\left[\mathrm{Cr}\left(\mathrm{C}_{10} \mathrm{H}_{13} \mathrm{NSO}_{2}\right)_{3}\right]\left(\mathrm{NO}_{3}\right)_{3} .3 \mathrm{H}_{2} \mathrm{O}$.

From the above discussed data and on the basis of relevant literature reports [51-54] we suggest that in compound $\mathrm{Cr}(\mathrm{ACTT})_{3}\left(\mathrm{NO}_{3}\right)_{3}\left(\mathrm{H}_{2} \mathrm{O}\right)_{3}$ (4), the chromium atom is six-coordinated to the three ACTT ligands in a tetragonal bipyramidal geometry. The non-coordinated nitrate ions and $\mathrm{H}_{2} \mathrm{O}$ molecules are randomly dispersed in the crystal lattice. Around the $\mathrm{Cr}$ atom which occupies the centre of the octahedral structure, two $\mathrm{N}$ atoms and two $\mathrm{O}$ atoms occupy each one of the four summits of the central square, whereas one $\mathrm{N}$ atom and one $\mathrm{O}$ atom are each fixed at one of the two edges of the vertical axis of the octahedron containing the metal atom. In this representation, as displayed in the optimized $3 \mathrm{D}$-view in Figure 2, the spatial proximity of the $\mathrm{H}$ atoms of the $-\mathrm{NH}_{2}$ groups with the $\mathrm{O}$ atoms of the carbonyl functions allow the optimal overlapping of the corresponding electron clouds and hence favors the formation of strong hydrogen bonds which contribute to the stability of the complex. Such stabilizing interactions are, however, less envisageable in the alternative structural representations of Figures 3 and 5 whose optimized 3D-views are shown in Figures 4 and 6 respectively.

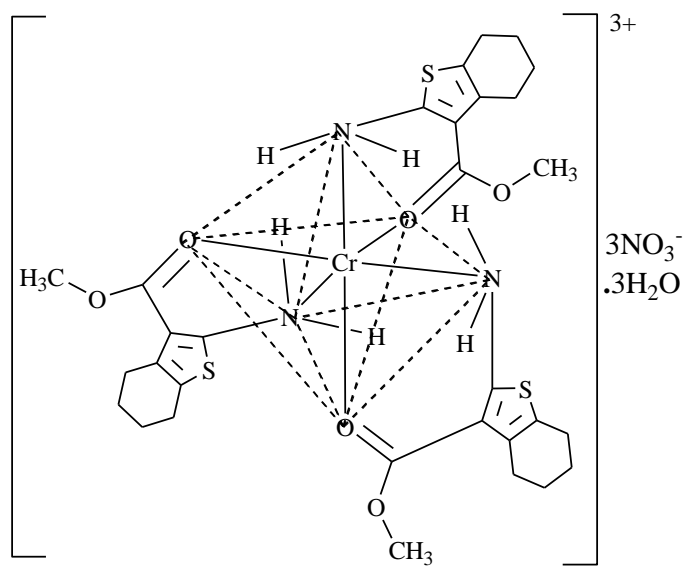

Figure 1. Structural representation of complex 4.

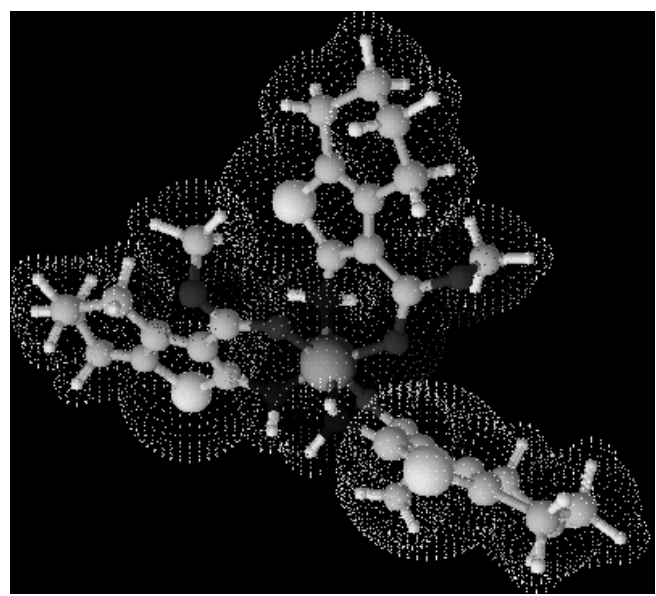

Figure 2. Optimized 3D view of the coordination sphere of complex 4 drawn with ACD/Labs 3D viewer (freeware).

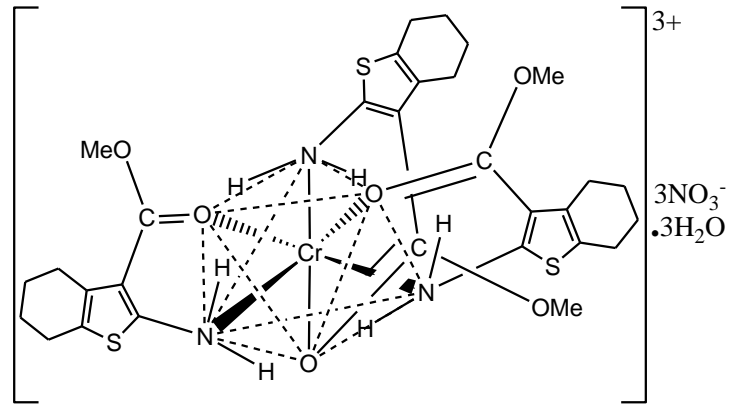

Figure 3. Structural representation of the isomer of complex 4.

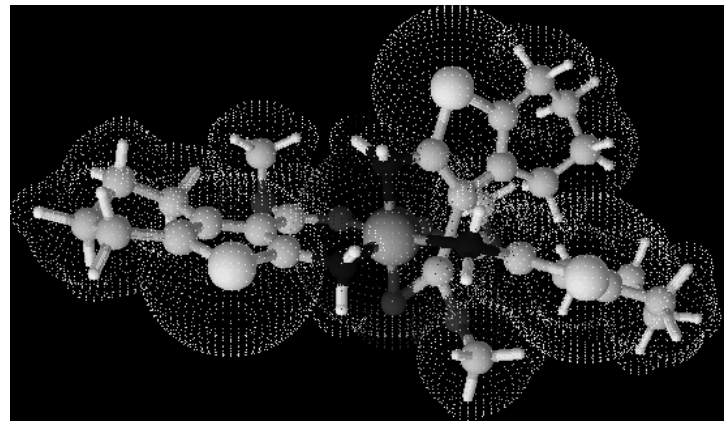

Figure 4. Optimized 3D view of the coordination sphere of the isomer of complex 4 drawn with ACD/Labs 3D viewer (freeware).

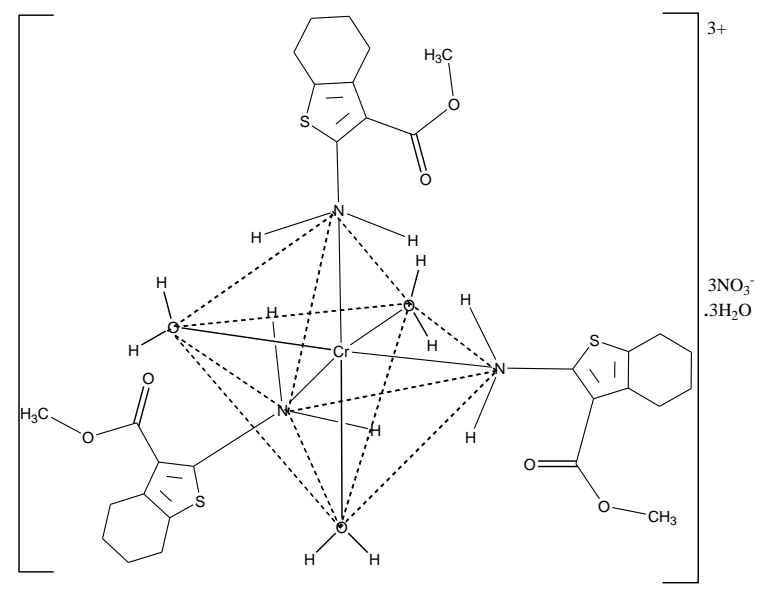

Figure 5. Structural representation of the isomer of complex 4.

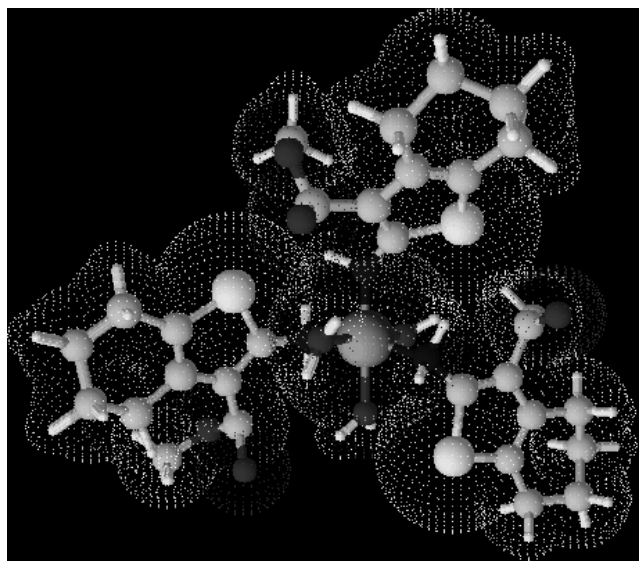

Figure 6. Optimized 3D view of the coordination sphere of the isomer of complex 4 drawn with ACD/Labs 3D viewer (freeware). 


\section{Geometric isomers}

The coordination core of complex 4 could be represented by the formula $\mathrm{MA}_{3} \mathrm{~B}_{3}$ where $\mathrm{M}$ represents the central chromium atom; A represents the nitrogen atom and $\mathrm{B}$ the carbonyl oxygen atom for each individual ACTT ligand involved in the complexation. There are therefore two possible geometric isomers. In one, the three coordinating atoms of each kind ( $\mathrm{N}$ or $\mathrm{O}$ ) of the ligands occupy opposite triangular faces of the octahedron; this is the fac isomer (for facial). In the other, the three coordinating atoms of each kind ( $\mathrm{N}$ or $\mathrm{O}$ ) of the ligands lie on what would be the meridian if the complex were viewed as a sphere; this is the mer isomer (for meridional)

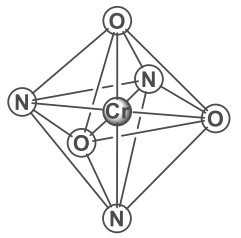

$\mathrm{MA}_{3} \mathrm{~B}_{3}$ octahedral, fac isomer

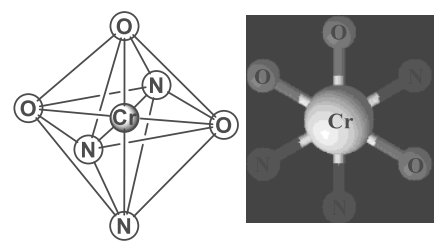

$\mathrm{MA}_{3} \mathrm{~B}_{3}$ octahedral, mer isomer
Figure 7. Structural representations of the two possible geometric isomers of complex 4.

\section{Optic isomers}

The coordination core of complex 4 with coordination numbers of six (Octahedral) have the potential to form also optical isomers. The absolute configuration of the chiral octahedral complex is described by imagining a view along a threefold rotation axis of the regular octahedron and noting the handedness of the helix formed by the ACTT ligands (Figure 8). Clockwise rotation of the helix is then designated $\Delta$ (delta) whereas the anticlockwise rotation is designated $\Lambda$ (lambda). We will have therefore the two optical isomers left-handed $\Lambda$ isomer $\left(\Lambda-\left[\mathrm{Cr}(\mathrm{ACTT})_{3}\right]^{3+}\right)$ and right-handed $\Delta$ isomer $(\Delta$ $\left.\left[\mathrm{Cr}(\mathrm{ACTT})_{3}\right]^{3+}\right)$

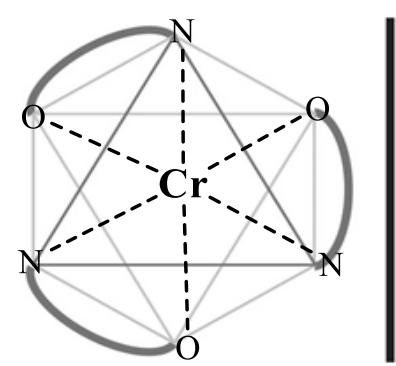

$\Lambda$

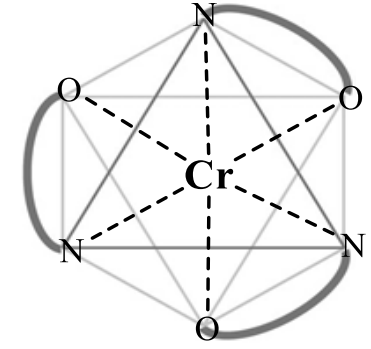

$\Delta$
Figure 8. Structural representations of the two possible optic isomers of complex 4.

\section{Biology Section}

The antimicrobial activity of the 2-amino-3-carbomethoxy-4,5,6,7tetrahydrobenzo [b]thiophene (3) and its chromium complex (4) was performed in vitro against bacterial and fungal species. No activity was detected prior to the formation of the complex independently of the tested microorganism (MIC > 252 $\mu \mathrm{g} / \mathrm{mL}$ ). Meanwhile, the chromium complex (4) derivative showed different degrees of antimicrobial activities (MIC $=4-16 \mu \mathrm{g} / \mathrm{mL}$ ) against the tested fungi and bacteria (Table 4$)$. The lowest MIC value $(4 \mu \mathrm{g} / \mathrm{mL})$ corresponding to the best antibacterial activity were recorded on Bacillus subtilis and Staphylococcus aureus. Interestingly, the activity against Staphylococcus aureus (MIC $=4$ $\mu \mathrm{g} / \mathrm{mL}$ ) was equal to that of ciprofoxacin ( $\mathrm{MIC}=4 \mu \mathrm{g} / \mathrm{mL}$ ) used as the antibacterial positive control. More interestingly, the inhibition of the growth of Bacillus subtilis by the complex (4) (MIC $=4 \mu \mathrm{g} / \mathrm{mL})$ was twice as efficient compared to the reference drug ciprofoxacin (MIC $=8 \mu \mathrm{g} / \mathrm{mL}$ ). All these observations highlight the good antibacterial potency of complex compound. The less sensitive microorganism was Shigella flexneri with the highest MIC (16 $\mu \mathrm{g} / \mathrm{mL})$ and $\mathrm{MBC}(32 \mu \mathrm{g} / \mathrm{mL})$ values recorded. The MBC and MFC values of this compound were four fold lesser than their corresponding MIC values; indicating that this compound has a microbicidal effect against the sensitive microorganisms [55]. The antibacterial activity of the chromium complex (4) are within the range of those other chromium complexes prepared respectively with N,N'-bis(benzoin)-1,4 butane diimine, mixed 2-hydroxybenzaldehyde and oxalic acid, mixed 9,10-phenanthrenequinone and 1,3-dicarbonyl-phenyldihydrazide, Anthraquinone Benzylthiosemicarbazone [52-54,56]. Compound 4 is however more active compared to their obtained results.

Overall, complex 4 was found to be little less antifungal ( $\mathrm{MIC}=8 \mu \mathrm{g} / \mathrm{mL}$ ) than antibacterial (MIC $=4-16 \mu \mathrm{g} / \mathrm{mL}$ ). However, the antifungal activity of $\mathbf{4}$ is still considered quite good as the rational minimum fungal concentration (MFC) to MFC/MIC was less than 4.

Table 4. Antimicrobial activity (MIC, MBC and MFC in $\mu \mathrm{g} / \mathrm{mL}$ ) of the chromium complex $\mathbf{4}$ against bacterial and yeast species.

\begin{tabular}{|c|c|c|c|}
\hline Microorganisms & $\begin{array}{l}\text { Inhibition } \\
\text { parameters }\end{array}$ & Complex & $\begin{array}{c}\text { Reference } \\
\text { drugs* }\end{array}$ \\
\hline \multirow{3}{*}{$\begin{array}{c}\text { Staphylococcus aureus } \\
\text { ATCC } 25923\end{array}$} & $\mathrm{MIC}$ & 8 & 2 \\
\hline & MBC & 16 & 2 \\
\hline & MBC/MIC & 2 & 1 \\
\hline \multirow{3}{*}{ Bacillus subtilis } & MIC & 4 & 8 \\
\hline & $\mathrm{MBC}$ & 4 & 8 \\
\hline & $\mathrm{MBC} / \mathrm{MIC}$ & 1 & 1 \\
\hline \multirow{3}{*}{ Staphylococcus aureus } & $\mathrm{MIC}$ & 4 & 4 \\
\hline & $\mathrm{MBC}$ & 4 & 4 \\
\hline & $\mathrm{MBC} / \mathrm{MIC}$ & 1 & 1 \\
\hline \multirow{3}{*}{$\begin{array}{c}\text { Pseudomonas } \\
\text { aeruginosa } \\
\text { ATCC } 27853\end{array}$} & MIC & 8 & 2 \\
\hline & $\mathrm{MBC}$ & 8 & 2 \\
\hline & $\mathrm{MBC} / \mathrm{MIC}$ & 1 & 1 \\
\hline \multirow{3}{*}{ Escherichia coli $S 2(1)$} & MIC & 8 & 4 \\
\hline & $\mathrm{MBC}$ & 16 & 4 \\
\hline & $\mathrm{MBC} / \mathrm{MIC}$ & 2 & 1 \\
\hline \multirow{3}{*}{ Shigella flexneri SDINT } & MIC & 16 & 4 \\
\hline & $\mathrm{MBC}$ & 32 & 4 \\
\hline & $\mathrm{MBC} / \mathrm{MIC}$ & 2 & 1 \\
\hline \multirow{3}{*}{$\begin{array}{l}\text { Candida albicans } \\
\text { ATCC } 10231\end{array}$} & $\mathrm{MIC}$ & 8 & 2 \\
\hline & $\mathrm{MFC}$ & 8 & 2 \\
\hline & MFC/MIC & 1 & 1 \\
\hline \multirow{3}{*}{$\begin{array}{c}\text { Candida tropicalis } \\
\text { PK233 }\end{array}$} & $\mathrm{MIC}$ & 8 & 4 \\
\hline & MFC & 8 & 4 \\
\hline & MFC/MIC & 1 & 1 \\
\hline \multirow{3}{*}{$\begin{array}{l}\text { Cryptococcus } \\
\text { neoformans } \mathrm{H} 99\end{array}$} & $\mathrm{MIC}$ & 8 & 4 \\
\hline & MFC & 8 & 4 \\
\hline & MFC/MIC & 1 & 1 \\
\hline
\end{tabular}

*Ciprofloxacin for bacteria and nystatin for yeasts; MIC: Minimum Inhibitory Concentration; MBC: Minimum Bactericidal Concentration; MFC: Minimum Fungicidal Concentration.

\section{Effects of chelation to the activity of compound complex}

After complexation reaction with the chromium salt, the initially non biological active ligand was converted into a biological well active compound. This observation leads to the conclusion that chelation is responsible for this new property. Upon chelation, the polarity of $\mathrm{Cr}$ (III) ion will be lowered to a greater extent due to the overlapping of ligand orbitals and partial sharing of the positive charge of the $\mathrm{Cr}$ (III) ion with donor groups [57]. Furthermore, the increased delocalization of $\pi$-electrons over the whole chelate ring might enhance lipophilicity of the complex. This increased lipophilicity might have enhanced the penetration of the complexes $\mathbf{4}$ into lipid membranes of the microorganisms and this may have blocked the metal binding sites of enzymes in the microorganisms as suggested in a related work [46]. It is also possible for metal complexes to disturb the respiration process of the cell and thus to block the synthesis of protein responsible for the growth of the microorganisms [27]. 


\section{CONCLUSION}

The new mononuclear chromium (III) containing three moieties of 2-amino-3carbomethoxy-4,5,6,7-tetrahydrobenzo[b]thiophene (ACTT) ligands has been successfully synthesized at room temperature and fully characterized by available elemental and spectroscopic data. Biological results showed that the complex displayed prominent antibacterial and antifungal activities with reference to a drug standard, whereas the ligand was found to be inactive. However, the antibacterial activities of complex on Staphylococcus aureus were found to be equal to ciprofoxacin, a reference drug. The antibacterial activities of the complex on Bacillus subtilis were found to be higher than that of ciprofoxacin. All these observations highlight the strong antibacterial potency of this complex. This complex can, therefore, be a very good alternative candidate to the fight against Bacillus subtilis.

\section{ACKNOWLEDGEMENTS}

Emmanuel Sopbué Fondjo gratefully acknowledges the financial support from DAAD (grant $\mathrm{N}^{\circ}$. 91691265). Additional financial supports for the work were obtained from the University of Dschang's research grant committee and the Cameroonian Ministry of Higher Education special research allocation.

\section{REFERENCES}

1. K. Aruna, S. Z. Bootwala, M. Tariq, C. Fernandes, Int. J. Pharm. Biological Sci. 5, 440, (2014)

2. S. Kumar, N. Kumar, Int. Curr. Pharm. J. 2, 91, (2013).

3. M. Bouachrine, O. Benaqqa, H. Toufik, M. Hamidi, J. - P. Lère-Porte, F. Serein-Spirau, A. Amine, Analele Universităţii din Bucur. 19, 44, (2010).

4. R. R. Zaky, A. M. Abdelghay, Res. J. Pharm. Biological Chem. Sci. 2, 764, (2011).

5. R. M. Mohareb, A. A. Fahmy, Eur. Chem. Bull. 2, 553, (2013).

6. A. Singh, S. P. Singh, A. Amalraj, P. D. Gokulan, P. Porwal, Int. J. Pharm. Biological Arch. 2, 540, (2011).

7. W. W. Wardakhana, N. A. Loucab, M. M. Kamel, Acta Chim. Slov. 54, 241, (2007).

8. V. Alagarsamy, D. Shankar, V. R. Solomon, Arkivoc xvi, 159, (2006).

9. B. Narayana, B. V. Ashalatha, K. K. V. Raj, N. S. Kumari, Indian J. Chem. 45B, 2703, (2006).

10. M. A. Gouda, H. F. Eldien, M. M. Girges, M. A. Berghot, Med. Chem. 3, 232, (2013)

11. S. Turk, M. Hrast, I. Sosi, H. Barreteau, D. Mengin-Lecreulx, D. Blanot, S. Gobec, Acta Chim. Slov. 60, 299, (2013).

12. K. - T. Wong, R. - T. Chen, Tetrahedron Lett. 43, 3317, (2002).

13. S. A. Khan, A. Y. Obaid, L. M. Al-Harb, M. N. Arshad, A. M. Asiri, M. B. Hursthouse, Int. J. Electrochem. Sci. 10, 2323, (2015).

14. N. R. Patil, R. M. Melavanki, H. D. Patil, D. Nagaraja, F. M. Sanningannavar, Int. J. Life Sci. Pharm. Res. 3, 76, (2013).

15. T. V. Dubinina, D. V. Dyumaeva, S. A. Trashin, M. V. Sedova, A. B. Karpo, V. I. Krasovskii, L. G. Tomilova, Macroheterocycles 5, 156, (2012).

16. F. A. Mohamed, A. E. El-Alfy, J. Appl. Sci. Res. 9, 183, (2013)

17. H. R. Maradiya, Turk. J. Chem. 25, 450, (2001).

18. Md. A. Hossain, Md. C. Sheikh, S. K. A. Z. Mahmud, Md. A. Alam, Int. J. Sci. Tech. Res. 2, 237, (2013).

19. R. M. S. Pereira, N. E. D. Andrades, N. Paulino, A. C. H. F. Sawaya, M. N. Eberlin, M. C. Marcucci, G. M. Favero, E. M. Novak, S. P. Bydlowski, Molecules 12, 1366, (2007).

20. A. D. Bansod, R. G. Mahale, A. S. Aswar, J. Indian Chem. Soc. 83, 781, (2006).

21. R. A. Yaul, V. V. Dhande, B. G. Pethe, A. S. Aswar, Bull. Chem. Soc. Ethiop. 28, 264, (2014)

22. V. B. Devi, P. Arulmozhichelvan, P. Murugakoothan, Int. J. ChemTech Res. 6, 2140, (2014)

23. A. A. Alemi, B. Shaabani, Acta Chim. Slov. 47, 369, (2000).

24. C. - C. Ko, W. - W. V. Yam, J. Mater. Chem. 20, 2070, (2010).

25. T. Yutaka, I. Mori, M. Kurihara, J. Mizutani, K. Kubo, S. Furusho, K. Matsumura, N. Tamai, H. Nishihara, Inorg. Chem. 40, 4995, (2001).

26. A. Samadi-Maybodi, S. K. H. Nejad-Darzi, R. Akhoondi, Int. Nano Lett. 1, 58, (2011).

27. M. Rizzotto in Search for Antibacterial Agents, A. V. Bobbarala ed. InTech, Croatia, 2012; pp. 80-81.

28. H. Al-Talib, A. Al-Khateeb, H. Hassan, Int. Med. J. 22, 3, (2015)

29. T. J. Foster, Fed. Eur. Microbiol. Soc. 41, 449, (2017).

30. M. Goncuoglu, F. S. B. Ormanc1, N. D. Ayaz, I. Erol Ann. Microbiol. 60, 494, (2010)
31. C. Kim, M. Fulke, A. Rahemi, T. Taghavi, A. Asmare, P. Kaseloo, E. Ndegwa, E. Sismour, EC Nutrition 13, 52, (2018)

32. A. - M. Guérout-Fleury, K. Shazand, N. Frandsen, P. Stragier, Gene 167, 336, (1995).

33. R. E. W. Hancock, D. P. Speert, Drug Resist. Updates 3, 255, (2000).

34. P. A. Lambert, J. R. Soc. Med. 95, 26, (2002).

35. S. Mehata, G. Duan, W. Zhang, Int. J. Infect. Microbiol. 1, 48, (2012).

36. A. A. M. Lima, J. J. C. Sidrim, N. L. Lima, W. Titlow, M. E. Evans, R. N. Greenberg, J. Clin. Microbiol. 35, 1065, (1997).

37. M. Sanguinetti, B. Posteraro, C. Lass-Flörl, Mycoses 58, 13, (2015).

38. M. Maroszyńska, A. Kunicka-Styczyńska, K. Rajkowska, I. Maroszyńska, Acta Biochim. Pol. 60, 724, (2013).

39. R. J. Kothavade, M. M. Kura, A. G. Valand, M. H. Panthak, J. Med Microbiol. 59, 880, (2010).

40. J. Santhanam, A. Fairuz, F. K. Ooi, A. H. Muhamad, J. Kesihat. Masy. Isu Khas 15, 53, (2002).

41. M. A. Maligie, C. P. Selitrennikoff, Agents Chemother. 49, 2856, (2005)

42. M. Lozano-Chiu, V. L. Paetznick, M. A. Ghannoum, J. H. Rex, J. Clin. Microbiol. 36, 2822, (1998)

43. E. S. Fondjo, D. A. Siéwé, J. - D. - D. Tamokou, S. E. Ekom, S. K. D. Djeukoua, G. Doungmo, M. E. Walters, A. Tsopmo, P. F. W. Simon, J. R. Kuiate, Acta Chim. Slov. 67, 211, (2020).

44. M. G. Reinecke, T. A. Woodrow, E. S. Brown, J. Org. Chem. 57, 1021 , (1992).

45. J. D. Tamokou, M. F. Tala, H. K. Wabo, J. - R. Kuiate, P. Tane, J. Ethnopharmacol. 124, 575, (2009).

46. S. S. Patil, M. M. Shaikh, Acta Pol. Pharm. Drug Res. 69, 686, (2012).

47. K. Nakamoto, Infrared and Raman spectra of inorganic and coordination compounds; Part B: Applications in coordination, organometallic, and bioinorganic chemistry, John Wiley \& Sons, New Jersey, (2009).

48. E. J. House, Inorganic Chemistry, Elsevier, San Diego, (2008).

49. K. K. Ilavenil, M. Dhamodharan, J. Chem. Pharm. Sci. 9, 1462, (2016).

50. C. Zhu, Y. Wang, Q. Mao, F. Li, Y. Li, C. Chen, Materials 313, 13, (2017)

51. A. Debnath, F. Hussain, D. T. Masram, Bioinorg. Chem. Appl. 2014, 8 , (2014).

52. V. Balamurugan, S. Sankar, Int. J. Res. Dev. Pharm. Life Sci. 4, 1327 (2015).

53. R. Al-Hassany, A. T. Mahmood, E. Z. Mohamed, A. A. Baqimaryoosh, A. A. R. Hussein, Acta Chim. Pharm. Indica 6, 25, (2016).

54. P. Jain, V. Singh, Der Pharm. Chem. 8, 180, (2016).

55. M. G. Djouossi, J. - D. Tamokou, D. Ngnokam, J. - R. Kuiate, L. A. Tapondjou, D. Harakat, L. Voutquenne-Nazabadioko, BMC Complementary Altern. Med. 15, 8, (2015).

56. J. S. Chandra, Y. A. S. J. P. Kumaria, P. N. V. V. L. P. Rania, Y Sunandamma, Indian J. Adv. Chem. Sci. 2, 37, (2013).

57. M. Thankamony, K. Mohanan, J. Serb. Chem. Soc. 46A, 251, (2007) 